\title{
Osmancık Şartlarında Yetiştirilen Bazı Çeltik Çeşitlerinin Verim Performanslarının Belirlenmesi
}

\author{
*Mevlüt ŞAHIN ${ }^{1}$ İsmail SEZER ${ }^{2}$ Orhan DENGIZ Fatih ÖNER $^{4}$ Hasan AKAY² \\ Abdulveli SIRAT ${ }^{5}$
}

\author{
${ }^{1}$ Tarla Bitkileri Merkez Araştırma Enstitüsü Müdürlüğü, Ankara \\ ${ }^{2}$ Ondokuz Mayıs Üniversitesi, Ziraat Fakültesi, Tarla Bitkileri Bölümü, Samsun \\ ${ }^{3}$ Ondokuz Mayıs Üniversitesi, Ziraat Fakültesi, Toprak Bölümü, Samsun \\ ${ }^{4}$ Ordu Üniversitesi, Ziraat Fakültesi, Tarla Bitkileri Bölümü, Ordu \\ ${ }^{5}$ Gümüşhane Üniversitesi Şiran Mustafa Beyaz Meslek Yüksek Okulu, Gümüşhane \\ *Sorumlu yazar e-posta (Corresponding author; e-mail): mevluts@yahoo.com
}

\section{Öz}

Bu araştırma, ülkemizde tescilli 12 çeltik çeşidinin (Osmancık 97, Neğiş, Aromatik-1, Beşer, 7721, Halilbey, Gönen, Karadeniz, Kızılırmak, Koral, Durağan ve Şumnu) Osmancık ilçesi şartlarında verim performanslarının ve kalite değerlerinin belirlenmesi amacıyla 2009 ve 2010 yılları arasında iki yıl süreyle yürütülmüştür. Denemeler tesadüf blokları deneme deseninde, üç tekerrürlü olarak Çorum İli Osmancık İlçesinde yürütülmüştür. En yüksek verim $805.1 \mathrm{~kg} / \mathrm{da}$ ile Osmancık 97 çeşidinden elde edilirken, bu çeşidi $788.5 \mathrm{~kg} / \mathrm{da}$ ile Beşer çeşidi takip etmiştir. En düşük verim $614.8 \mathrm{~kg} / \mathrm{da}$ ile Neğiş çeşidinden elde edilmiştir. Araştırma sırasında verim, bitki boyu, salkım uzunluğu, salkımda tane sayısı, bin tane ağırlığı ve kırıksız randıman gibi kalite ve verim unsurları ayrı ayrı incelenmiştir.

Anahtar Kelimeler: Çeltik çeşitleri, verim, kalite kriterleri

\section{Determination of The Yield Performances of Some Rice Varietıes Under Osmancık Conditions}

\begin{abstract}
This research was conducted to determine of yield and quqlity parameters of rice varieties for ecological conditions of Osmancik in 2009-2010. Twelve rice cultivars (Osmancık 97, Neğiş, Aromatik-1, Beşer, 7721, Halilbey, Gönen, Karadeniz, Kızılırmak, Koral, Durağan and Şumnu) were used as a material for the study. The study was carried out in the Randomized Complete Block design with three replications in Osmancik conditions. The highest yields were obtained from Osmancik $97(805.1 \mathrm{~kg} / \mathrm{da})$ varieties, this type of followed by Beser $(788.5 \mathrm{~kg} / \mathrm{da})$ varietie. The lowest yield was obtained from Negis $(614.8 \mathrm{~kg} / \mathrm{da})$ varietie. At this study, yield, plant height, panicle lenght, seed number per panicle, 1000 seed weight and seed production performance without broken seeds were investigated.
\end{abstract}

Keywords: Rice varieties, yield, quality criteria

\section{Giriş}

$\mathrm{T}$ ahıllar dünyadaki besin ihtiyacının \%80'ini karşılamaktadır. Sıcak iklim tahılları arasında yer alan çeltik (Oryza sativa L.) dünya nüfusunun yaklaşık yarıdan fazlasının besin kaynağı olarak yararlandığı en önemli tahıl ürünlerinden birisidir (Khush 1997). Çeltik önemli bir gıda maddesi olup, dünyada en fazla üretim yapılan ürünler içerisinde ikinci sırada yer alır. Dünyanın yarıdan fazlası, özellikle gelişmiş ülkeler çeltik üretimine önem vermektedir (Boyer 1982). Hızla artan dünya nüfusunun beslenme intiyacını karşılamak için tahıl üretimi giderek daha fazla önem kazanmaktadır. Dünyada kişi başına günlük enerjinin \%25'i pirinç tüketimi ile karşılanmaktadır. Dünya genelindeki nüfus artış hızı bu oranda devam ettiği takdirde 2030 yılında talebi karşılamak için çeltik üretiminin tüm dünya genelinde olduğu gibi ülkemizde de $\% 50$ oranında artırılması gerekmektedir (FAO 2002).

Çeltiğin protein içeriği diğer tahıllarla karşılaştırıldığında oldukça yüksektir. Çeltik bileşimi beslenme için gerekli amino asitlerce zengin olması nedeniyle insan beslenmesinde 
buğdaydan sonra en çok kullanılan üründür (Elçi ve ark 1994). Pirinçte birçok bitki proteininde az bulunan lisin ve threonin yaklaşık \%4 seviyesinde bulunmaktadır (Sürek 2002). Pirinç tüm dünyada özellikle hayvansal proteinin pahalı olduğu gelişen ülkelerde önemli bir kalori ve protein kaynağıdır. Asya'daki besin diyetlerinin proteinlerine pirinç \%28 - \%54 arasında katkıda bulunmaktadır (Duff 1991).

Türkiye'de 2014 yılı verilerine göre çeltik ekim alanı 110.884 ha, üretim 830.000 ton ve dekara verim ise $764 \mathrm{~kg}$ 'dır (Anonim 2015).

\section{Materyal ve Yöntem}

Bu çalışmada materyal olarak 12 adet çeltik çeşidi (Aramotik-1, Osmancık, Neğis, Beşer, 7721, Halilbey, Gönen, Karadeniz, Kızılırmak, Koral, Durağan ve Şumnu) kullanılmıştır. Denemeler 2009 ve 2010 çeltik yetiştirme sezonunda, tesadüf blokları deneme deseninde 3 tekrarlamalı olarak Çorum iline bağlı Osmancık ilçesinde çiftçi arazisinde kurulmuştur. Denemeye alınan çeltik çeşitleri ekilirken, serpme ekimde uygulanan tohum miktarına dönük araştırmalar dikkate alınarak $m^{2 x}$ ye 500 tohum düşecek şekilde hesaplama yapılmıştır (Sezer ve Köycü 1994). Ölçüm ve gözlemler, Tarım, Gıda ve Hayvancılık Bakanlığı Koruma ve Kontrol Genel Müdürlüğü’nün "Tarımsal Değerleri Ölçme Denemeleri Teknik Talimatı” ile Uluslararası Çeltik Araştırma Enstitüsü (IRRI)'nün çeltik için hazırlamış olduğu "Standart Değerlendirme Sistemi" birlikte dikkate alınarak yapılmıştır. Verilerin değerlendirilmesinde SASJMP istatistik paket programı kullanılmıştır. Çoklu karşılaştırma testlerinden ise LSD testi kullanılarak gruplandırmalar yapılmıştır.

\section{Bulgular ve Tartışma}

\section{Bitki Boyu}

On iki çeltik çeşidinde bitki boyu bakımından çeşitler arasında istatistiki açıdan çok önemli $(P<0.01)$ fark görülmüştür. Bitki boyu en düşük $76.97 \mathrm{~cm}$ ile Aromatik-1 çeşidinden elde edilmişken, en yüksek ise $100.3 \mathrm{~cm}$ ile Gönen çeşidinden elde edilmiştir. (Çizelge 1). Bitki boyu bakımından denemenin doğruluk derecesi (\% $\mathrm{CV}$ ) ise 2.27 olarak belirlenmiştir. Bitki boyu tahıllarda verim, verim unsurları ve kalite bakımından üzerinde en fazla durulan morfolojik özelliklerden birisidir (Kırtok ve ark. 1987; Genç ve ark. 1993; Kün, 1996). Yapılan bir çalışmada bitki boyu $76-165 \mathrm{~cm}$ arasında bulunmuştur (Zaman ve ark. 2005). Denemeden elde edilen bitki boyları bu çalışma ile uyum içerisindedir.

\section{Salkımda Tane Sayısı}

Salkımda tane sayısı bakımından çeşitler arasında istatistiki açıdan çok önemli $(P<0.01)$ fark bulunmuştur. Salkımda tane sayısı en düşük 53.32 adet ile Aromatik-1 çeşidinden elde edilmiş iken, en yüksek 96.05 adet ile Halilbey çeşidinden elde edilmiştir. Salkımda tane sayısı bakımından denememizin doğruluk derecesi (\% CV) ise 12.71 olarak bulunmuştur (Çizelge 1). Araştırmada elde edilen sonuçları diğer araştırıcıların sonuçlarıyla karşılaştırdığımızda, salkımda tane sayısını 53-108.4 adet arasında bulan Köycü ve ark. (1994); 81.7-109.3 adet arasında bulan Sezer ve Köycü (1999); 48-75 adet arasında bulan Anonim (2001)'in bildirdiği salkımda tane sayısı değerleri araştırmamızda bulduğumuz değerlerle paralellik göstermektedir. Ancak, salkımda tane sayısını 120-146.9 arasında bulan Sharief et al. (2005); 96-175 adet arasında bulan Totak ve ark. (2008)ın belirttiği salkımda tane sayısı araştırmada bulunan salkımda tane sayısından fazladır. Bunun sebebi salkımda tane sayısının çeşit özelliklerinden ve çevre şartlarından etkilenmesidir.

\section{Bintane Ağırığı}

Yapılan istatistiki analiz sonucunda çeltik çeşitleri arasında bintane ağılığı bakımından istatistiki açıdan çok önemli $(P<0.01)$ fark bulunmuştur. Bintane ağırlığı en düşük 24.08 gr ile Aromatik-1 çeşidinden elde edilmişken, en yüksek bintane ağırlığı ise $36.07 \mathrm{gr}$ ile Gönen çeşidinden elde edilmiştir. Araştırmada elde edilen sonuçları diğer araştırıcıların sonuçlarıyla karşılaştırdığımızda, bulduğumuz bin tane ağırlığı değerlerinin, bin tane ağırığını 32.2-38 g arasında bulan Şahin ve ark. (2011); 30-34 g arasında bulan Düzgün ve ark. (1990); 27.19-39.7 g arasında bulan Şavşatlı ve Gülümser (2006); 29-36.1 g arasında bulan Açıkgöz ve Sekin (1984); 30.1$38 \mathrm{~g}$ arasında bulan Anonim (2002) ile uyum göstermektedir.

\section{Kırıksız Randıman}

Kırıksız randıman bakımından denemede kullanılan çeşitler arasında istatistiki açıdan çok önemli $(P<0.01)$ fark bulunmuştur. Kırıksız randıman en düşük \%50.21 ile Beşer çeşidinde, en yüksek ise \%66.39 ile Durağan çeşidinden elde edilmiştir. Kırıksız randıman bakımından ise denemenin doğruluk derecesi (\% CV) ise 2.93 olarak belirlenmiştir (Çizelge 1). 
Çizelge 1. Çeltik çeşitlerinin bitki boyu, salkım uzunluğu, salkımda dane sayısı, bintane ağırlığı, kırıksız randıman ve dekara verim bakımından varyans analiz sonuçları ve LSD karşılaştırmaları.

Table 1. Plant heights (BB), panicle lengths (SU), seed numbers per panicle (STS), 1000 seed weights (BTA), seed performances without broken seeds (KR) and yield ( $\mathrm{kg} / \mathrm{da})(\mathrm{DV})$ of rice varieties, variance analysis results and $L S D$ groups.

\begin{tabular}{lcccccc}
\hline \multicolumn{1}{c}{ Çeşitler } & BB & SU & STS & BTA & KR & DV \\
\hline Osmancık 97 & $85.53 \mathrm{e}$ & $14.60 \mathrm{~cd}$ & $82.01 \mathrm{ab}$ & $31.21 \mathrm{e}$ & $59.31 \mathrm{bc}$ & $727.93 \mathrm{ab}$ \\
Neğiş & $96.46 \mathrm{~b}$ & $15.82 \mathrm{~b}$ & $56.42 \mathrm{c}$ & $35.11 \mathrm{~b}$ & $54.62 \mathrm{e}$ & $547.30 \mathrm{de}$ \\
Aromatik-1 & $76.97 \mathrm{~h}$ & $15.78 \mathrm{~b}$ & $53.32 \mathrm{c}$ & $24.08 \mathrm{I}$ & $44.39 \mathrm{~g}$ & $440.34 \mathrm{e}$ \\
Beşer & $84.26 \mathrm{ef}$ & $16.90 \mathrm{a}$ & $84.43 \mathrm{ab}$ & $34.13 \mathrm{c}$ & $50.21 \mathrm{f}$ & $698.35 \mathrm{abc}$ \\
7721 & $81.27 \mathrm{fg}$ & $12.76 \mathrm{e}$ & $78.32 \mathrm{~b}$ & $29.87 \mathrm{f}$ & $57.87 \mathrm{bcd}$ & $678.68 \mathrm{abc}$ \\
Halilbey & $91.00 \mathrm{~cd}$ & $15.21 \mathrm{bc}$ & $96.05 \mathrm{a}$ & $32.26 \mathrm{~d}$ & $60.17 \mathrm{bc}$ & $763.33 \mathrm{a}$ \\
Gönen & $100.3 \mathrm{a}$ & $17.11 \mathrm{a}$ & $75.71 \mathrm{~b}$ & $36.07 \mathrm{a}$ & $59.96 \mathrm{bc}$ & $608.91 \mathrm{~cd}$ \\
Karadeniz & $98.09 \mathrm{a}$ & $17.51 \mathrm{a}$ & $84.05 \mathrm{ab}$ & $33.78 \mathrm{c}$ & $55.68 \mathrm{de}$ & $636.96 \mathrm{bcd}$ \\
Kızılırmak & $89.80 \mathrm{~d}$ & $15.27 \mathrm{bc}$ & $78.36 \mathrm{~b}$ & $26.81 \mathrm{~h}$ & $51.21 \mathrm{f}$ & $619.89 \mathrm{bcd}$ \\
Koral & $94.23 \mathrm{bc}$ & $17.20 \mathrm{a}$ & $76.78 \mathrm{~b}$ & $28.38 \mathrm{~g}$ & $60.46 \mathrm{~b}$ & $607.26 \mathrm{~cd}$ \\
Durağan & $84.34 \mathrm{ef}$ & $13.26 \mathrm{e}$ & $83.23 \mathrm{ab}$ & $30.98 \mathrm{e}$ & $66.39 \mathrm{a}$ & $657.26 \mathrm{abcd}$ \\
Şumnu & $77.98 \mathrm{gh}$ & $13.70 \mathrm{de}$ & $77.18 \mathrm{~b}$ & $27.27 \mathrm{~h}$ & $57.55 \mathrm{~cd}$ & $668.39 \mathrm{abc}$ \\
\hline Önemlilik & $\star *$ & $* *$ & $\star * *$ & & $*$ & $*$ \\
LSD & 3.38 & 0.959 & 16.61 & 0.4 & 2.826 & 116.76 \\
CV & 2.27 & 3.63 & 12.71 & 1.5 & 2.93 & 10.81 \\
\hline
\end{tabular}

BB: Bitki boyu (cm), SU: Salkım uzunluğu (cm), STS: Salkımda tane sayısı (adet), BTA: Bintane ağırı̆ı̆ı (g), KR: Kırıksız randıman (\%), DV: Dekara verim $(\mathrm{kg} / \mathrm{da})$,

LSD: En küçük önemli fark, CV: Denemenin doğruluk derecesi $(\%)^{* *} \mathrm{P}<0.01$

LSD: Least Significant Difference, CV: Coefficient of Variance $(\%){ }^{* *} P<0.01$

Araştırmada elde edilen sonuçları diğer araştırıcıların sonuçlarıyla karşılaştırdığımızda; kırıksız randımanı \%49-64.6 arasında bulan Açıkgöz ve Sekin (1984); \%47.5-65.3 arasında bulan Gravois et al. (1991); \%55.2-65.5 arasında bulan Dok ve ark. (2001); \%54.4-62.8 arasında bulan Anonim (2002); 36.4-55.4 arasında bulan Anonim (2003); \%43.1-60.8 arasında bulan Anonim (2006); \%49.2-61.9 arasında bulan Sürek ve ark. (2007); \%58.665.4 arasında bulan Blanche et al. (2009), ile uyum göstermektedir. Ancak, kırıksız randımanı \%62.8-70.9 arasında bulan Teceren ve ark. (1996)'ın elde ettiği sonuçlarla uyum göstermemektedir. Çünkü kırıksız pirinç randımanı yıllara çeşitlere ve çevre koşullarına göre değişim göstermektedir (Clement and Seguy, 1994).

\section{Dekara Verim}

Çeşitler arasında dekara verim bakımından çok önemli $(P<0.01)$ fark bulunmuştur. En düşük dekara verim $440.34 \mathrm{~kg}$ ile Aromatik-1 çeşidinden elde edilirken, en yüksek dekara verim $763.33 \mathrm{~kg}$ il Halilbey çeşidinden elde edilmiştir. Yapılan istatistik analiz sonucunda Osmancık 97, Beşer, 7721, Durağan ve Şumnu çeşitleri ile en yüksek verim veren Halilbey çeşidi ile aynı grupta toplanmıştır. Dolayısıyla bu çeşitler arasında dekara verim bakımından fark yoktur. Dekara verim bakımından denemenin doğruluk derecesi (\% CV) ise 10.81 olarak belirlenmiştir (Çizelge 1). Araştırmada elde edilen tane verimi değerlerini diğer araştırıcıların sonuçlarıyla karşılaştırdığımızda, tane verimini $726.7-766.0 \mathrm{~kg} / \mathrm{da}$ arasında bulan Inayatullah et al. (1989); $511-578 \mathrm{~kg} / \mathrm{da}$ arasında bulan Ülger ve Genç (1989); 968.4$622.5 \mathrm{~kg} / \mathrm{da}$ arasında bulan Sezer ve Köycü (1999); 766.0-658.5 kg/da arasında bulan Şavşatı ı ve Gülümser (2006); 464-474 arasında bulan Latif ve ark. (2007); $625.6-789.6 \mathrm{~kg} / \mathrm{da}$ arasında bulan, Köycü ve ark. (1994); 602-715 kg/da arasında bulan Şahin ve ark. (2005); 483-655 kg/da arasında bulan Kaya ve ark. (2009)'nın açıkladığı değerlere paralellik gösterdiği görülmüştür. Tane verimini 769.0$1242 \mathrm{~kg} / \mathrm{da}$ arasında bulan Düzgün ve ark. (1990)'ın belirttiği değerler, bu araştırma sonuçlarından daha yüksek bulunmuştur.

\section{Sonuç}

Tahıllar dünyadaki besin intiyacının \%80'ini karşılamaktadır. Sıcak iklim tahılları arasında yer alan, çeltik dünya nüfusunun yaklaşık yarıdan fazlasının besin kaynağı olarak yararlandığı en önemli tahı ürünlerden birisidir.

Çeşitlerin bitki boyu $76.97-100.3 \mathrm{~cm}$, salkım uzunluğu $13.26-16.90 \mathrm{~cm}$, salkımda tane sayısı 53.32-96.05 adet, bintane ağırlığı 24.08-36.07 gr, kırıksız randıman \%50.21-66.39 ve dekara verim $440.34-763.33 \mathrm{~kg}$ arasında değişim göstermiştir. Osmancık şartlarında dekara verimi en yüksek Halilbey, Osmancık-97, Beşer, 7721, Durağan ve Şumnu çeşitleri yetiştirilebilecek çeşit olarak önerilebilir. 


\section{Kaynaklar}

Açıkgöz N. ve Sekin Y., 1984. Ege Bölgesi Ekolojik Koşullarında Yetiştirilen Farklı Kökenli Çeltik Çeşitlerinde Tane ve Kimi Kalite Özellikleri Üzerine Bir Araştırma. Ege Üni. Ziraat Fak. Dergisi, 21: 51-69

Anonim, 2001. Karadeniz Bölgesi Çeltik Islahı Çalışmaları Projesi Sonuç Raporu (Yayınlanmamış), Proje No: TAGEM/00/01/01/02. Karadeniz Tarımsal Araştırma Enstitüsü. Samsun

Anonim, 2002. Trakya Tarımsal Araştırma Enstitüsü, ülkesel çeltik araştırmaları Projesi, 2001 Yılı Gelişme Raporu (Yayınlanmamış)

Anonim, 2003. Tarımsal Değerleri Ölçme Denemeleri Teknik Talimatı, Çeltik (Oryza sativa L.) Tarım ve Köyişleri Bakanlığı Koruma ve Kontrol Genel Müdürlüğü, Ankara

Anonim, 2015. Türkiye Çeltik Ekiliş-Üretim-Verim ve TMO Alımları. http://www.tmo.gov.tr/Upload/ Document/istatistikler/Çizelgelar/6celtikeuva. pdf (Erişim tarihi 23.07.2015.)

Blanche S.B., Utomo H.S., Wenefrida I. and Myers G.O., 2009. Genotype x environment Interactions of hybrid and varietal rice cultivars for grain yield and milling quality. Crop Science, 49(6): 2011-2018

Boyer J.S., 1982. Plant productivity and environment. Science, 218: 443-448

Clement G. and Seguy J.L., 1994. Le Comportement Dur İ Al Usinage.Agriculture at Development, 3: 38-46

Dok M., Torun M., Sahin M., Gizlenci S. and Yulafcı A., 2001. Determining the Optimum Water Draining and Harvesting Time on Rice (Oryza sativa L.) Yield and Output in Samsun. International Rice Symposium on Genetic Reseources Breeding for Europe and Other Temperate Areas

Duff B., 1991. Trends And Patterns in Asian Rice Consumption. In: Marketing and Quality Issues, 1-22. International Rice Research Institute, Manila, Philippines

Düzgün M., Nigiş M. ve Konuk H., 1990. Çeltikte Çeşit Belirleme. Çukurova Tarımsal Araştırma Enstitüsü, Müdürlüğü Yayın No: 10, S:32

Elçi S., Gecit H. ve Kolsarıcı O., 1994. Tarla Bitkileri Ders Kitabı. Ankara Universitesi, Tarla Bitkileri Bölümü, Ankara

FAO, 2002. Global IPM facility available http://faostat.fao.org/

Genç İ., Yağbasanlar T. ve Ozkan H., 1993. Akdeniz İklim Kuşağına Uygun Makarnalık Buğday
Çeşitlerinin Belirlenmesi Üzerinde Araştırmalar. Makarnalık Buğday Mamulleri Sempozyumu, 30 Kasım - 3 Aralık, Ankara, $127-141$

Gençtan T., İlhami O.A. ve Başer İ., 1994. Çeltikte tane verimi ile bazı verim unsurları arasındaki ilişkilerin path analizi ile belirlenmesi. Trakya Üni. Tekirdağ Zir. Fakültesi, (1-2): 158-165

Gravois K.A., Moldenhauer K.A.K. and Rohman P.C., 1991. Genetic and genotype X environment effects for rough rice and head rice yields. Crop Science, 31(4): 907-911

Kırtok Y, Genç İ, Çölkesen M, 1987. ICARDA Kökenli Bazı Arpa Çeşitlerinin Çukurova Koşullarında Başlıca Tarımsal Karakterleri Üzerinde Araştırmalar. TÜBITAK Türkiye Tahıl Sempozyumu, 6-9 Ekim, Bursa, TOAG, 83-90

Khush G.S., 1997. Origin, dispersal, cultivation and variation of rice. Plant Molecular Biology, 35: 25-34

Kün E., 1996. Tahıllar-I (Serin İklim Tahılları). Ankara Üniv. Ziraat Fakültesi Yayınları, Yayın No:1451, Ankara

Nasır A.L. and Arıyo O.J., 2006. Stability analysis of grain yield of rice planted in an Inland swamp ecology. J. Sustain Agric. Environ., 8(2): 156158

Ogunbayo S.A., Ojo D.K., Guei R.G., Oyelakin O.O. and Sanni K.A., 2005. Phylogenetic diversity and relationships among 40 rice accessions using morphological and rapds techniques. African Journal of Biotechnology, 4(11): 1234-1244

Sezer İ. ve Köycü C., 1994. Çeltiğin Verim, Verim Unsurları ile Bazı Kalite Karakterlerine Ekim Yöntemi ve Bitki Sıklığının Etkileri Üzerine Bir Araştırma. E.Ü.Z.F. Tarla Bitkileri Kongresi, 25-29 Nisan 1994, İzmir, Agronomi Bildirileri, Cilt 1: S.72, İzmir

Sharief A.E., EL-Moursy S.A., Salama A.M., ELEmery M.I. and Youssef F.E., 2005. Morphological and molecular biochemical identification of some rice (Oryza sativa L.) cultivars. Pakistan Journal of Biological Science, 2(9): 1275-1279

Şahin M., Öner F., Üre T., Sezer İ., 2011. Çeltik çeşit ya da çeşit adaylarının karadeniz bölgesi şartlarında performanslarının belirlenmesi. Ondokuz Mayıs Üni., 4. Tohumculuk Kongresi, s.133-137, Samsun

Şavşatlı Y. ve Gülümser A., 2006. Fideleme ve serpme ekim yöntemlerinin bazı çeltik çeşitlerinde verim ve kalite karakterlerine etkileri. OMU Zir. Fak. Dergisi, 21(2): 154-159 
Sürek H., 2002. Çeltik Tarımı. Hasad Yayıncılık Ltd. Şti, İstanbul

Sürek H., Beser N., Kaya R., Yatkın O. ve Kuşku H., 2007. Son Yirmi Yılda Ülkemizde Çeltik Üretiminde Elde Edilen Genetik İlerlemenin Tespiti. Sonuç Raporu Proje No:TAGEM/TA/04/03/06/001. Trakya Tarımsal Araştırma Enstitüsü

Teceren M., Yuğut F. ve Bektas H.T., 1996. Çeşit Tescil Denemeleri Sonunda Tescil Olan Çeltik Çeşitleri ve Bunların Özellikleri. Bitki Islahı Sempozyumu 15-17 Ekim, İzmir, s.204-211
Totok A.D.H. and Yoshida T., 2008. Yield stability of aromatic upland rice witkh high yielding ability in Indonesia. Plant Prod. Sci., 11(1): 96-103

Zaman M.R., Paul D.N.R., Kabir M.S., Mahbub M.A.A. and Bhuiya M.A.A., 2005. Assessment of character contribution to the divergence for rice varieties. Asian Journal of Plant Sciences, 4(4): 388-391 